\title{
The mRNA and protein expression of ruminal MCT1 is increased by feeding a mixed hay/concentrate diet compared with hay ad libitum diet (Short Communication)
}

Judith Kuzinski' and Monika Röntgen²

${ }^{1}$ Research Unit Muscle Biology and Growth, ${ }^{2}$ Research Unit Nutritional Physiology »Oskar Kellner«, Leibniz Institute for Farm Animal Biology (FBN), Dummerstorf, Germany

\begin{abstract}
In this study the protein and mRNA expression of Monocarboxylate transporter 1 (MCT1) was evaluated in rumen epithelial cells (REC) obtained from sheep fed hay ad libitum (control, $h$ diet, $n=4)$ or a mixed hay/concentrate diet ( $h / c$ diet, $n=4)$ for two weeks. REC were isolated via fractionated trypsination and three groups consisting of fractions 3 to $5=\mathrm{G} 1$, fractions 6 to $8=\mathrm{G} 2$, and fractions 9 and $10=\mathrm{G} 3$ were formed. Using an anti-basal cytokeratin antibody and flow cytometric analysis, the proportion of REC originating from the stratum basale (SB) was determined for each group. In addition, MCT1 mRNA and protein expression was determined by qRT-PCR and Western blot, respectively. Feeding the $\mathrm{h} / \mathrm{c}$ diet led to a $299 \pm 93 \%$ elevation of the number of SB cells known to express the MCT1 protein. This is accompanied by an increased MCT1 mRNA (1.8 to 2.2-fold) and protein (1.3-fold) expression. Thus, an increased number of MCT1 expressing cells and upregulation of ruminal MCT1 protein seem to be components of rumen epithelium functional adaptation to high energy diet.
\end{abstract}

Keywords: sheep, rumen, epithelial cells, transport protein, high energy diet

\section{Zusammenfassung}

\section{Die mRNA- und Protein-Expression des MCT1 in Pansenepithelzellen wird durch Zufütterung von Konzentrat zu einer ad libitum Heu-Ration erhöht}

In der vorliegenden Studie wurden die mRNA- und Proteinexpression des Monocarboxylattransporters 1 (MCT1) in Pansenepithelzellen (PEZ) von Schafen, die über zwei Wochen entweder Heu ad libitum ( $h$-Diät, $n=4$ ) oder eine Heu/Konzentrat-Mischration ( $h / c-D i a ̈ t, ~ n=4)$ erhielten, untersucht. Ovine PEZ wurden mittels fraktionierter Trypsinierung gewonnen und anschließend drei Zellgruppen, bestehend aus den Fraktionen 3-5 (G1), 6-8 (G2) und 9/10 (G3), zugeordnet. Mittels Flowzytometrie und unter Nutzung eines spezifischen Antikörpers gegen basales Cytokeratin wurde der Anteil von PEZ aus dem Stratum basale (SB) für jede Zellgruppe ermittelt. Die Expression von MCT1-mRNA und -Protein wurde mittels qRT-PCR und Western Blot analysiert. Die Anzahl MCT1-exprimierender SB-Zellen, stieg nach Füt-

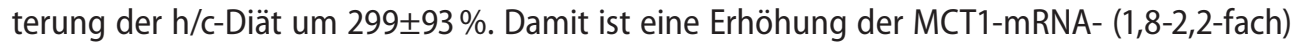
sowie der Proteinexpression (1,3-fach) verbunden. Ein erhöhter Anteil MCT1-expremierender PEZ und die Aufregulation der MCT1 Proteinmenge scheinen somit Komponenten der funktionellen Anpassung des Pansenepithels an energiereiche Fütterung darzustellen. 
Schlüsselwörter: Schaf, Pansen, Epithelzellen, Transportprotein, energiereiche Fütterung

\section{Introduction}

In the ruminant, short-chain fatty acids (SCFA) produced by the anaerobic microbial fermentation of carbohydrates cover up to $80 \%$ of the energy requirements of these animals (Siciliano-Jones \& Murphy 1989, Bergmann 1990). Its absorption is known to occur by passive diffusion of undissociated acids but also include the apical uptake of SCFA anions in exchange for bicarbonate (Kramer et al. 1996, Gäbel \& Sehested 1997). Following uptake into rumen epithelial cells (REC), SCFA particularly butyrate are metabolized to hardly membrane-permeant ketone bodies, namely acetoacetate and B-hydroxybutyrate (BHB). The transport of these metabolites from rumen epithelium to the blood is facilitated by a large-conductance anion channel in the basolateral membrane (Stumpff et al. 2009) and by the Monocarboxylate transporter 1 (MCT1). The carrier is known to be dominantly located in the cell membrane of REC from the stratum basale (SB) (Müller et al. 2002, Taifor et al. 2009) and to mediate a cotransport of its substrates (ketone bodies, lactate, pyruvate) with protons (Müller et al. 2002, Koho et al. 2005, Kirat et al. 2006, Graham et al. 2007). Thus, MCT1 possesses an important role in transepithelial transfer of nutrients and in rumen $\mathrm{pH}$ regulation (Müller et al. 2002, Gäbel \& Aschenbach 2006, Kirat et al. 2005, Kirat et al. 2006).

Recent studies revealed the SCFA butyrate as a main factor inducing MCT1 mRNA and protein upregulation in the human colon (Cuff et al. 2002). Ruminal butyrate concentrations are known to increase with high-energy diets (Gäbel et al. 1987, Shen et al. 2004). Thus, we hypothesize that an elevated MCT1 expression could be a main factor contributing to the rumen epithelium adaptative response to high intraruminal SCFA concentrations and low $\mathrm{pH}$ values.

Therefore, using isolated REC, we have analysed the mRNA and protein expression of ruminal MCT1 after feeding hay ad libitum (h diet) or a mixed hay/concentrate diet ( $\mathrm{h} / \mathrm{c}$ diet) over a time period of two weeks.

\section{Material and methods}

The experimental design and methods have been described elsewere in detail (Kuzinski et al. 2011). In preparation to the experiment, 8 male castrated lambs were fed the $h$ diet for one week. Thereafter, animals were divided into two groups ( $\mathrm{n}=4$ each) and received the $\mathrm{h}$ diet for another two weeks or a h/c diet. The amount of concentrate supplement (10.2 MJ $\mathrm{ME} / \mathrm{kg} ; 16 \% \mathrm{CP}$ ) was stepwise increased from 150 to $1000 \mathrm{~g} /$ day and given in two meals. After slaughter REC were isolated via fractional trypsination (Galfi et al. 1981). Fractions 1 and 2 contained mostly cornified cells and were discarded. Then, three groups (G1-G3) of REC were formed by pooling REC originating from fractions 3 to 5,6 to 8 and 9/10, respectively. REC $\left(1 \times 10^{7}\right)$ from each group were fixed in $20 \mathrm{ml}$ methanol and then, using an anti-basal cytokeratin antibody (RCK103; abcam, Cambridge, UK) and flow cytometric analysis, the proportion of cells originating from the SB was determined. The results are summarized in Figure 1, showing a $326 \pm 142 \%$ and $479 \pm 168 \%$ increase of basal cytokeratin expressing cells in the G2 and G3 REC fractions from $\mathrm{h} / \mathrm{c}$-fed compared to h-fed sheep. 


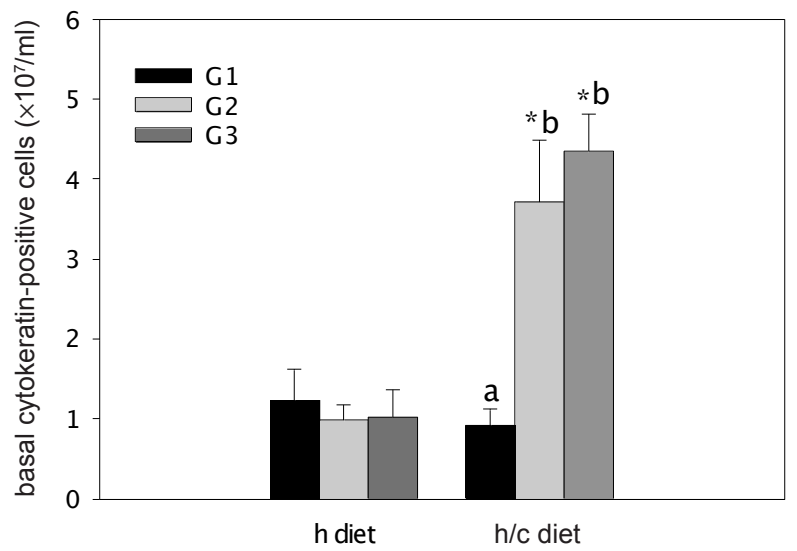

Values are means \pm standard error (SE), n: 4 per diet. ${ }^{*} P<0.05$ between diet groups, ${ }^{\mathrm{a} / \mathrm{b}} P<0.05$ between cell groups within a diet group.

Figure 1

Number of REC positive for basal cytokeratin in cell populations derived from fractions 3 to $5=\mathrm{G} 1,6$ to $8=\mathrm{G} 2$ and $9 / 10=\mathrm{G} 3$ of fractional trypsination

RNA and protein samples were prepared using commercial kits (M-PER Mammalian Protein Extraction Reagent, Pierce, Bonn, Germany; NucleoSpin RNA II, Macherey-Nagel, Düren Germany) and MCT1 expression (mRNA and protein) was determined by performing qRTPCR and Western Blot. Bovine MCT1-specific oligonucleotides (NM_001037319.1: 5'- CTT CTG TAA CAC TGT GCA GGA ACT-3' and 5'- CGT AGA TCA TAA AGA AAG CCT GGT-3'; transcript size: $206 \mathrm{bp}$ ) were used to detect the abundance of MCT1 mRNA transcripts. The amount of MCT1 mRNA was normalized against the mRNA amount of the ribosomal protein S18 (S18) used as housekeeping gene (NM_001033614: 5'- CTT AAA CAG ACA GAA GGA CGT GAA-3' and 5'- CCA CAC ATT ATT TCT TCT TGG ACA-3'; transcript size: 218 bp). REC total protein samples of $15 \mu \mathrm{g}$ were used for Western Blotting analysis. For MCT1 protein detection a monoclonal chicken anti-MCT1 antibody (AB1286, Millipore) raised against the carboxyl-terminal of rat MCT1 (1:5000 dilution) and a horseradishperoxidase (HRP)-conjugated secondary antichicken IgG antibody (Sigma-Aldrich, Munich, Germany; 1:5000 dilution) were used. Protein quantification was done by densitometric analysis with ImageJ freeware (National Institutes of Health) and the percentage change of MCT1 protein abundance in REC from h/c-compared to h-fed sheep was calculated. Data were analysed by the Student's t-test using SigmaStat (Jandel Scientific). $P<0.05$ was considered to be significant.

\section{Results}

As shown in Figure 2A, PCR revealed the MCT1 in ovine REC. The product obtained corresponded to the calculated base number (206 bp) of the sequence produced by the primers. This result was confirmed by sequencing the PCR products, yielding an identity of $97 \%$ homology. In REC obtained from h-fed sheep the concentration of MCT1 mRNA decreased from $0.43 \pm 0.14 \mathrm{pg}$ per pg S18 mRNA in G1 to $0.23 \pm 0.06 \mathrm{pg}$ per pg S18 mRNA in G3 (Figure 2B). In contrast, in REC isolated from sheep fed the $\mathrm{h} / \mathrm{c}$ diet the MCT1 mRNA amount increased from $0.30 \pm 0.05 \mathrm{pg}$ per pg S18 mRNA in G1 to $0.51 \pm 0.17$ pg per pg S18 mRNA in G3. Feeding the $\mathrm{h} / \mathrm{c}$ diet tends $(P=0.069)$ to increase ruminal MCT1 mRNA concentration in $\mathrm{G} 2$. Compared to $\mathrm{G} 2$ cells $(0.26 \pm 0.04 \mathrm{pg}$ per pg S18 mRNA) from sheep fed the $h$ diet, it amounted to $0.47 \pm 0.07$ pg per pg S18 mRNA in G2 cells from h/c-fed sheep. 
A

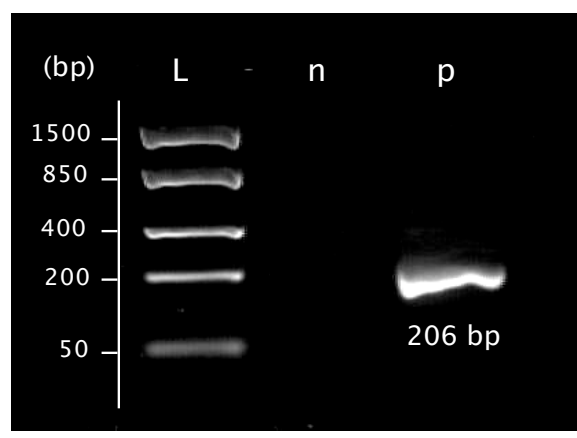

SYBR-Gold-stained $2 \%$ agarose gel of RT-PCR products for DNA size ladder (bp, lane L), negative control (lane $\mathrm{n}$, without reverse transcriptase), and MCT1 (lane p). The product obtained with the MCT1specific primer has the expected size of $206 \mathrm{bp}$.

\section{B}

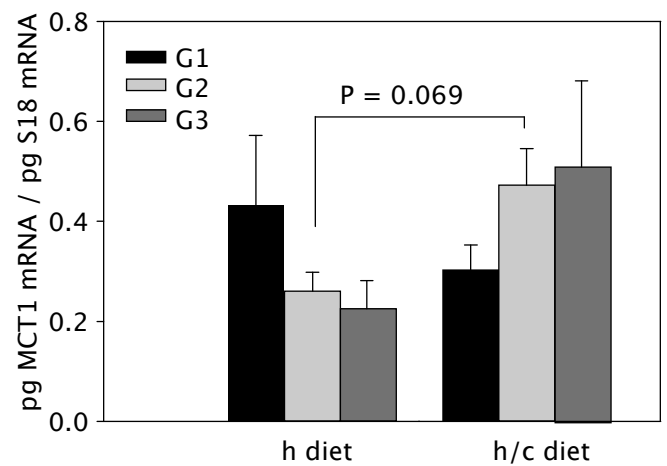

Expression of MCT1 mRNA in G1 to G3 REC fractions of h-fed or h/c-fed sheep. Values have been normalized to the S18 signal. Values are means \pm standard error (SE), $\mathrm{n}: 4$ per diet.

Figure 2

Expression of MCT1 mRNA in ovine rumen epithelial cells (REC) of sheep fed hay ad libitum (h diet) or a mixed hay/concentrate diet (h/c diet) for 14 days

\section{A}

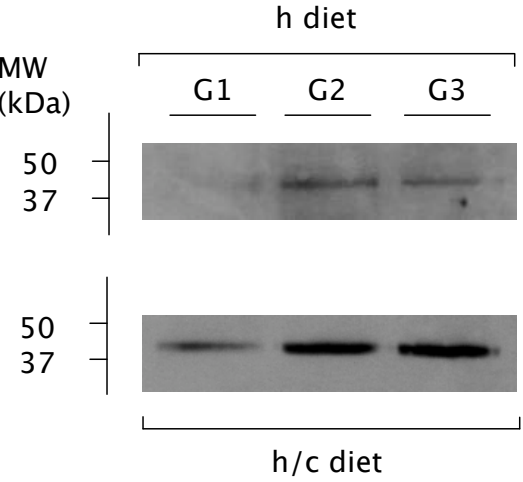

Representative example of a MCT1 Western blot, used for the ImageJ analysis. The anti-MCT1 antibody detected bands at the expected sizes of $\sim 45 \mathrm{kDa}$.

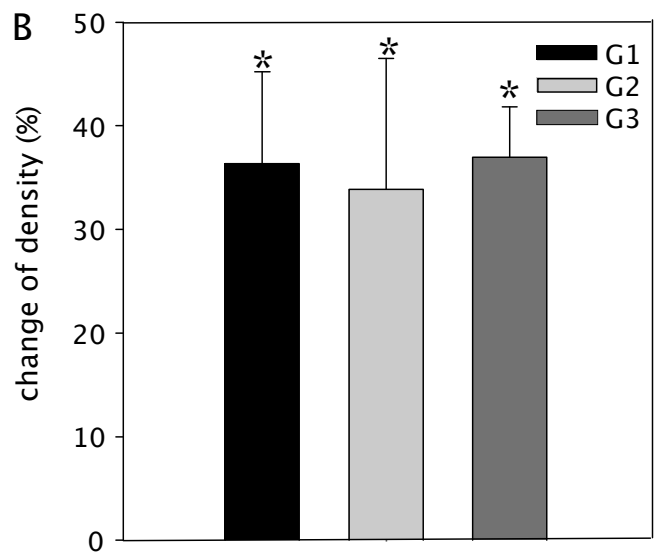

Relative abundances of the $\sim 45 \mathrm{kDa}$ band in ovine REC isolated from sheep fed the h- or h/c-diet. Densitometric analysis was performed by using ImageJ freeware. The percentage increase of the MCT1 protein amount in REC from $\mathrm{h} / \mathrm{c}$-fed sheep in relation to its abundance in REC from $\mathrm{h}$-fed sheep is shown. Values are means \pm standard error (SE); $\mathrm{n:} 4$ per diet; ${ }^{*} P<0.05$ between diet groups.

Figure 3

Expression of MCT1 protein in ovine rumen epithelial cells (REC) of sheep fed hay ad libitum diet or a mixed hay/concentrate diet for two weeks 
Typical Western blots of whole cell protein extracts derived from G1 to G3 REC populations of h- or h/c-fed sheep are presented in Figure $3 \mathrm{~A}$ and show a band at the expected molecular mass of about $45 \mathrm{kDa}$ in $\mathrm{G} 1$ to $\mathrm{G} 3$ fractions of both treatment groups. The higher MCT1 protein expression in REC isolated from h/c-fed sheep (Figure 3A) was confirmed by downstream densitometric analysis. Compared to the h-group, the pixel density, reflecting the MCT1

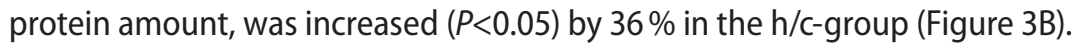

\section{Discussion}

In human colon epithelial cells the SCFA butyrate has been shown to stimulate the MCT1 promoter activity (Borthakur et al. 2008) and to induce MCT1 upregulation at the mRNA (5.7fold) and protein (5.2-fold) level (Cuff et al. 2002). Functionally, these changes are reflected by an increased butyrate uptake. In the present study, the ruminal butyrate concentration was $6.8 \pm 0.4 \mathrm{mmol} / \mathrm{l}$ in $\mathrm{h}$-fed sheep and increased to $17.3 \pm 1.2 \mathrm{mmol} / \mathrm{l}(P<0.001)$ after feeding the $h / c$ diet (Kuzinski et al. 2011). Thus, elevated butyrate concentrations could be a trigger for the upregulation of MCT1 mRNA (1.8- and 2.2-fold in G2 and G3, respectively) and protein expression (1.3-fold) observed in h/c-fed sheep. However, it should be emphasized that besides substrate induction, MCT1 and its chaperon CD147 can be upregulated by nutritiondependent activation of the transcription factor peroxisome proliferator-activated receptor a (PPAR-a) (König et al. 2010). The presence and correct conformation of CD147, is essential for correct membrane assembly and functional activity of MCT1 (Kirk et al. 2000, Wilson et al. 2005).

As the MCT1 protein exists exclusively in basal cells (Müller et al. 2002, Taifor et al. 2009), the extreme increase in the number of REC originating from SB in G2 and G3 cell populations from $\mathrm{h} / \mathrm{c}$-sheep gives an additional explanation for the observed results. In accordance with our data, bulls fed concentrate ad libitum during the finishing period showed significantly higher abundance of ruminal MCT1 protein than bulls fed only $50 \%$ of their daily ad libitum consumption (Koho et al. 2010). Taken into account the functional role of MCT1 for transepithelial SCFA absorption and ruminal fluid as well as REC $\mathrm{pH}$ regulation (Gäbel et al. 2002, Müller et al. 2002, Kirat et al. 2006, Graham et al. 2007), our results point to an important role of an increased MCT1 expression for the functional adaptation of rumen epithelium to a high energy diet.

In conclusion, a fast proliferation and thus increased number of MCT1 expressing SB cells accompanied by a transcriptional upregulation of the MCT1 protein in REC of the deeper epithelial cell layers (G2/G3) are important mechanisms to accelerate SCFA absorption and to avoid a disturbed $\mathrm{pH}$ regulation with its negative consequences on rumen epithelium function and structure.

\section{Acknowledgements}

We thank R. Brose and H. Pröhl (Leibniz Institute for Farm Animal Biology (FBN), Dummerstorf) for their excellent technical assistance. We also thank the staff of animal husbandry of the FBN Dummerstorf and of the Faculty of Agriculture and Environment at the University of Rostock. This study was supported by the DFG (M. Schweigel, SCHW 642/5-2). 


\section{References}

Bergmann EN (1990) Energy contributions of volatile fatty acids from the gastrointestinal tract in various species. Physiol Rev 70, 567-590

Borthakur A, Saksena S, Gill RK, Alrefai WA, Ramaswamy K, Dudeja PK (2008) Regulation of Monocarboxylate Transporter 1 (MCT1) Promoter by butyrate in human intestinal epithelial cells: Involvement of NF-KB pathway. J Cell Biochem 103, 1452-1463

Cuff MA, Lambert DW, Shirazi-Beechey SP (2002) Substrate-induced regulation of the human colonic monocarboxylate transporter, MCT1. J Physiol 539, 361-371

Galfi P, Neogrady S, Kutas F (1981) Culture of ruminal epithelial cells from bovine ruminal mucosa. Vet Res Commun 4, 295-300

Graham C, Gatherar I, Haslam I, Glanville M, Simmons NL (2007) Expression and localization of monocarboxylate transporters and sodium/proton exchangers in bovine rumen epithelium. Am J Physiol Regul Integr Comp Physiol 292, R997-R1007

Gäbel G, Aschenbach JR (2006) Ruminal SCFA absorption: channelling acids without harm. In: Sejrsen K, Hvelplund T, Nielsen MO (eds.) Ruminant Physiology: Digestion, metabolism and impact of nutrition on gene expression, immunology and stress. Wageningen Academic Publishers, Wageningen, The Netherlands, 173-195

Gäbel G, Aschenbach JR, Müller F (2002) Transfer of energy substrates across the ruminal epithelium: implications and limitations. Anim Health Res Rev 3, 15-30

Gäbel G, Martens H, Sündermann M, Galfi P (1987) The effect of diet, intraruminal pH and osmolarity on sodium, chloride and magnesium absorption from the temporarily isolated and washed reticulo-rumen of the sheep. Quart J Exp Physiol 72, 501-511

Gäbel G, Sehested J (1997) Section F: Comparative aspects of SCFA supply and absorption. SCFA transport in the forestomach of ruminants. Comp Biochem Physiol 118A, 367-374

Kirat D, Inoue H, Iwano H, Hirayama K, Yokota H, Taniyama H, Kato S (2005) Monocarboxylate transporter 1 gene expression in the ovine gastrointestinal tract. Vet J 171, 462-467

Kirat D, Masuoka J, Hayashi H, Iwano H, Yokota H, Taniyama H, Kato S (2006) Monocarboxylate transporter 1 (MCT1) plays a direct role in short chain fatty acids absorption in caprine rumen. J Physiol 576, 635-647

Kirk P, Wilson MC, Heddle C, Brown MH, Barclay AN, Halestrap AP (2000) CD147 is tightly associated with lactate transporters MCT1 and MCT4 and facilitates their cell surface expression. EMBO J 19, 3896-3904

Koho N, Maijala V, Norberg H, Nieminen M, Pösö AR (2005) Expression of MCT1, MCT2 and MCT4 in the rumen, small intestine and liver of reindeer (Rangifer tarandus tarandus L.). Comp Biochem Physiol 141A, 29-34

Koho NM, Taponen J, Tiihonen H, Manninen M, Pösö AR (2010) Effects of age and concentrate feeding on the expression of MCT1 and CD147 in the gastrointestinal tract of goats and Hereford finishing beef bulls. Res Vet Sci, doi:10.1016/j.rvsc.2010.06.002

Kramer T, Michelberger T, Gürtler H, Gäbel G (1996) Absorption of short-chain fatty acids across ruminal epithelium of sheep. J Comp Physiol 166B, 262-269

Kuzinski J, Zitnan R, Viergutz T, Legath J, Schweigel M (2011) Altered $\mathrm{Na}^{+} / \mathrm{K}^{+}$-ATPase expression plays a role in rumen epithelium adaptation in sheep fed hay ad libitum or a mixed hay/concentrate diet. Vet Med 56, 35-47

König B, Fischer S, Schlotte S, Wen G, Eder K, Stangl GI (2010) Monocarboxylate transporter 1 and CD147 are up-regulated by natural and synthetic peroxisome proliferators-activated receptor a agonists in livers of rodents and pigs. Mol Nutr Food Res 54, 1-9

Müller F, Huber K, Pfannkuche H, Aschenbach JR, Breves G, Gäbel G (2002) Transport of ketone bodies and lactate in the sheep ruminal epithelium by monocarboxylate transporter 1. Am J Physiol 283, G1139-G1146

Siciliano-Jones J, Murphy MR (1989) Production of volatile fatty acids in the rumen and cecum-colon of steers as affected by forage:concentrate and forage physical form. J Dairy Sci 72, 485-492 
Shen Z, Seyfert HM, Löhrke B, Schneider F, Zitnan R, Chudy A, Kuhla S, Hammon H, Blum JW, Martens H, Hagemeister H, Voigt J (2004) An energy-rich diet causes rumen papillae proliferation associated with more IGF type 1 receptors and increased plasma IGF-1 concentrations in young goats. J Nutr 134, 11-17

Stumpff F, Martens H, Bilk S, Aschenbach JR, Gäbel G (2009) Cultured ruminal epithelial cells express a largeconductance channel permeable to chloride, bicarbonate, and acetate. Pflugers Arch 457, 1003-1022

Taifor F, Steinhoff J, Pfannkuche H, Hammon HM, Gäbel G (2009) Developmental influences on the expression of MCT1 in the rumen, reticulum and omasum of neonatal calves. Proc Soc Nutr Physiol 18, 138

Wilson MC, Meredith D, Fox JE, Manoharan C, Davies AJ, Halestrap AP (2005) Basigin (CD147) is the target for organomercurial inhibition of monocarboxylate transporter isoforms 1 and 4: the ancillary protein for the insensitive MCT2 is EMBIGIN (gp70). J Biol Chem 280, 27213-27221

Received 21 March 2011, accepted 2 May 2011.

Corresponding author:

Monika Röntgen formerly Schweigel

email: roentgen@fbn-dummerstorf.de

Forschungsbereich Ernährungsphysiologie »Oskar Kellner«, Leibniz-Institut für Nutztierbiologie (FBN), Wilhelm-Stahl-Allee 2, 18196 Dummerstorf, Germany 